\title{
Pengaruh Teh Hijau Terhadap Kadar Gula Darah dan MDA Serum Mencit Diabetes
}

\author{
Rizka Karima Husfa ${ }^{1}$, Erlina Rustam ${ }^{2}$, Hasmiwati ${ }^{3}$ \\ ${ }^{1}$ Fakultas Kedokteran Universitas Andalas Padang \\ ${ }^{2}$ Bagian Farmakologi Fakultas Kedokteran Universitas Andalas Padang \\ ${ }^{3}$ Bagian Parasitologi Fakultas Kedokteran Universitas Andalas Padang
}

\section{A B S T R A C T}

\begin{abstract}
Latar Belakang. Diabetes melitus merupakan penyakit metabolik kronik yang ditandai dengan hiperglikemia, jika terjadi secara terus-menerus akan menghasilkan radikal bebas berlebihan yang berperan dalam komplikasi diabetes. Teh hijau memiliki banyak kandungan katekin yang berperan sebagai antihiperglikemik dan antioksidan untuk mencegah komplikasi diabetes.
\end{abstract}

Objektif. Penelitian ini bertujuan untuk mengetahui pengaruh pemberian teh hijau terhadap kadar gula darah dan MDA serum mencit yang diinduksi aloksan.

Metode. Penelitian ini merupakan true experimental dengan randomized post-test control group design. Sampel terdiri dari 35 ekor mencit yang dibagi menjadi lima kelompok, yaitu kelompok kontrol negatif $(\mathrm{K}-)$, kontrol positif $(\mathrm{K}+)$, perlakuan 1 (P1), perlakuan 2 (P2), dan perlakuan 3 (P3). Kelompok Kadalah kelompok normal yang hanya diberikan diet standar, kelompok $\mathrm{K}+$ diinduksi aloksan saja, kelompok P1, P2, dan P3 diinduksi aloksan dan diberi infusa teh hijau $1 \%, 2 \%$, dan $4 \%$ selama 15 hari.

Hasil. Rata-rata kadar gula darah kelompok K-, K+, P1, P2, dan P3 adalah 73,14 mg/dl, $210 \mathrm{mg} / \mathrm{dl}, 164,57 \mathrm{mg} / \mathrm{dl}, 152,57 \mathrm{mg} / \mathrm{dl}$, dan $135,83 \mathrm{mg} / \mathrm{dl}$. Terdapat perbedaan signifikan antara kelompok P1, P2, dan P3 dengan kelompok $\mathrm{K}+$ dengan nilai $p=0,001$. Rata-rata kadar MDA serum kelompok K-, K+, P1, P2, dan P3 adalah 2,54 $\mathrm{nmol} / \mathrm{mg}, 4,04 \mathrm{nmol} / \mathrm{mg}, 3,05 \mathrm{nmol} / \mathrm{mg}$, $2,87 \mathrm{nmol} / \mathrm{mg}$, dan $2,47 \mathrm{nmol} / \mathrm{mg}$. Terdapat perbedaan signifikan antara kelompok P1, P2, dan P3 dengan kelompok $\mathrm{K}+$ dengan nilai $p=0,001$.

Kesimpulan. Pemberian infusa teh hijau berpengaruh terhadap penurunan kadar gula darah dan MDA serum mencit yang diinduksi aloksan.

Kata kunci: teh hijau, Camellia sinensis, diabetes melitus, gula darah, MDA serum, aloksan.

Background. Diabetes mellitus is a chronic metabolic disease, characterized by hyperglycemia which if occurs continously will produce excessive free radical that have role in diabetes complication. Green tea has a lot of cathecin which has role as antihyperglycemia and antioxidant to prevent diabetes complication.

Objective. The aim of this research is to determine the effect of green tea on blood glucose level and serum MDA level in alloxan-induced mice. This research was a true experiment with randomized post-test control group design. The sample consisted of 35 mice divided into five groups, negative control $(K-)$, positive control $(K+)$, treatment $1(P 1)$, treatment $2(P 2)$, and treatment $3(P 3)$. The $K$ - group was the normal group, given standard diet only, the K+ group was induced alloxan only, the $P 1, P 2$, and $P 3$ groups were induced alloxan and given $1 \%, 2 \%$, and $4 \%$ green tea infusion for 15 days.

Result. The mean of blood glucose level on $K-, K+, P 1, P 2$, and $P 3$ group were $73,14 \mathrm{mg} / \mathrm{dl}, 210 \mathrm{mg} / \mathrm{dl}, 164,57 \mathrm{mg} / \mathrm{dl}, 152,57$ $\mathrm{mg} / \mathrm{dl}$, and $135,83 \mathrm{mg} / \mathrm{dl}$. There were significant difference between $P 1, P 2$, and $P 3$ group with $K+$ group with $p$ value $=0,001$. The mean of serum MDA level on $K-, K+, P 1, P 2$, and P3 group were $2,54 \mathrm{nmol} / \mathrm{mg}, 4,04 \mathrm{nmol} / \mathrm{mg}, 3,05$ $\mathrm{nmol} / \mathrm{mg}, 2,87 \mathrm{nmol} / \mathrm{mg}$, and $2,47 \mathrm{nmol} / \mathrm{mg}$. There were significant difference between $P 1, P 2$, and $P 3$ group with $K+$ group with $p$ value $=0,001$.

Conclusion. Green tea infusion can reduce the level of blood glucose and serum MDA in alloxan-induced mice.

Keywords: green tea, Camellia sinensis, diabetes mellitus, blood glucose, serum MDA, alloxan

Apa yang sudah diketahui tentang topik ini?

- Diabetes merupakan penyakit kronis yang dapat menimbulkan komplikasi pada jaringan tubuh jika tidak ditatalaksana.

- Teh hijau memiliki efek antihiperglikemik dan antioksidan.

\section{Apa yang ditambahkan pada studi ini?}

Kajian ini membahas tentang peranan teh hijau sebagai antihiperglikemia dan antioksidan dalam menurunkan kadar gula darah dan MDA serum hewan coba.

\section{CORRESPONDING AUTHOR}

Name: Rizka Karima Husfa

Phone: +628576166 8325

E-mail: rizkakarimahusfa@gmail.com

\section{ARTICLE INFORMATION}

Received: September $23^{\text {rd }}, 2020$

Revised: October $15^{\text {th }}, 2020$

Available online: October $31^{\text {st }}$, 2020 


\section{Pendahuluan}

Diabetes Melitus (DM) adalah suatu penyakit kronis, disebabkan oleh kekurangan produksi insulin yang diturunkan atau didapat, atau disebabkan karena tidak efektifnya kerja dari insulin walaupun produksinya mencukupi. ${ }^{1}$ Terganggunya produksi insulin ataupun kinerja insulin ini akan menyebabkan terjadinya peningkatan konsentrasi kadar gula dalam darah, yang disebut dengan keadaan hiperglikemia. Secara klinis, keadaan ini akan menimbulkan gejala-gejala DM. ${ }^{2}$

Jenis DM yang paling sering ditemukan adalah DM tipe 2, disebabkan oleh kurangnya sekresi insulin dan resistensi insulin pada jaringan tubuh, dan disertai oleh faktor lingkungan lainnya. Sedangkan DM tipe 1 disebabkan mutlak oleh defisiensi insulin. ${ }^{2}$ Kedua penyebab DM ini akan menyebabkan keadaan hiperglikemia yang terjadi secara kronik ataupun akut secara terus menerus, pada akhirnya akan berdampak buruk pada sistem-sistem di dalam tubuh manusia dan akhirnya menimbulkan komplikasi. ${ }^{1,2}$ Keadaan hiperglikemia ini akan menyebabkan kerusakan pada jaringan secara langsung melalui stres oksidatif ataupun glikosilasi yang meluas. ${ }^{2}$ Selain itu stres oksidatif juga ikut berkontribusi dalam peningkatan resistensi insulin dan terganggunya produksi insulin dalam patogenesis DM tipe $2 .^{3}$

Stres oksidatif adalah keadaan dimana prooksidan terbentuk lebih banyak dibandingkan dengan antioksidan yang disebabkan karena hilangnya keseimbangan antara keduanya. 4,5 Gangguan dalam tubuh ini tidak hanya menyebabkan peroksidasi lemak dan kerusakan DNA, tapi juga mengganggu adaptasi fisiologis dan regulasi transduksi sinyal intraseluler. Adanya biomarker untuk menandakan adanya dugaan luasnya stres oksidatif yang terjadi menjadi hal yang menarik dari sudut pandang klinis. Marker yang ditemukan di dalam darah, urin dan cairan tubuh lainnya mungkin bisa memberikan informasi untuk menegakkan diagnosis. Salah satu biomarker yang digunakan untuk mendeteksi produk dari hasil stres oksidatif yang digunakan adalah dengan mengukur kadar malondialdehid (MDA). ${ }^{5}$

International Diabetes Federation (IDF) memperkirakan bahwa 1 dari 11 orang usia 20-79 tahun, yaitu sekitar 415 juta orang yang mengalami DM pada tahun 2015. Perkiraan ini digambarkan akan meningkat menjadi 642 juta pada tahun 2040, dan peningkatan yang sangat besar akan muncul dari daerah dengan transisi level ekonomi rendah ke level ekonomi sedang. ${ }^{6}$

Di Indonesia, data Riskesdas 2013 menunjukkan bahwa diperkirakan 6,9\% penduduk Indonesia usia 15 tahun keatas menderita DM. Sedangkan pada Riskesdas 2018 menunjukkan adanya peningkatan menjadi 10,9\% penduduk Indonesia yang mengalami DM. Peningkatan prevalansi DM juga terjadi di Sumatra Barat, yang pada tahun 2013 sebanyak $1,2 \%$ meningkat menjadi $1,8 \%$ pada tahun $2018 .^{7}$

Diabetes melitus sudah menjadi epidemi di seluruh dunia. Hal utama yang paling diperhatikan dari keadaan ini ialah perkembangan dari komplikasi kronis yang disebabkan karena keadaan DM terus menerus. Khususnya komplikasi DM yang sudah diklasifikasikan menjadi komplikasi mikrovaskular (retinopati, nefropati dan neuropati) atau komplikasi makrovaskular (penyakit kardiovaskular, serebrovaskular dan penyakit vaskular perifer). ${ }^{8}$

Pada seseorang dengan DM, tujuan utama tatalaksana klinis adalah merancang regimen yang dapat memperbaiki faktor metabolik yang berasosiasi dengan perkembangan dan progresifitas dari komplikasi, seperti merancang bagaimana menargetkan tekanan darah, kadar lemak dalam darah, dan kadar gula darah. Strateginya terdiri dari modifikasi gaya hidup saja, terdiri dari modifikasi diet dan peningkatan aktivitas fisik, atau dikombinasikan dengan intervensi farmakologikal. Namun, pasien sangat tertarik pada strategi alternatif yang terdiri dari diet suplementasi yang berasal dari produk alami seperti dari sumber tumbuh-tumbuhan atau tanaman herbal karena alami dan sudah dipraktekkan sebagai salah satu bagian dari budaya dari generasi ke generasi. ${ }^{8}$

Salah satu tumbuhan yang sudah dikonsumsi dari jaman dahulu adalah teh atau Camellia sinensis. Camellia sinensis sudah ditemukan pada 2700 SM di Cina dan sampai saat ini teh menjadi minuman yang paling banyak dikonsumsi setelah air putih di seluruh dunia. ${ }^{9}$ Tumbuhan ini berasal dari dataran Cina, Asia Selatan dan Asia Tenggara. Namun sekarang sudah ditanam di daerah-daerah tropis dan subtropis lain di dunia. Tumbuhan ini berbentuk semak berdaun hijau atau pohon kecil 
yang tingginya dibawah 2 meter, yang biasanya ditanam untuk diambil daunnya. 10

Camellia sinensis dilaporkan mengandung sekitar 4000 komponen bioaktif, yang sepertiganya adalah polifenol. ${ }^{11}$ Polifenol adalah metabolit sekunder tumbuhan dan secara umum bertugas dalam perlindungan dari radiasi ultraviolet atau serangan dari patogen. Dalam dekade terakhir, sudah banyak ketertarikan dalam manfaat kesehatan yang potensial dari tumbuhan yang memiliki polifenol sebagai antioksidan. Konsumsi diet tumbuhan kaya polifenol memberi perlindungan dari kanker, penyakit kardiovaskular, DM, osteoporosis dan penyakit neurodegeneratif. ${ }^{12}$

Polifenol yang terdapat pada Camellia sinensis adalah katekin. Katekin dalam Camellia sinensis memiliki kemampuan 100 kali lebih efektif dari vitamin C dan 25 kali lebih efektif dari vitamin E dalam menetralisir radikal bebas. ${ }^{13}$ Jenis katekin yang tedapat pada Camellia sinensis adalah epicathechin (EC), epicathechin gallate (ECG), epigallocathecin (EGC) dan epigallocathechin-3gallate (EGCG). ${ }^{11}$ Katekin berperan sebagai antioksidan dan bekerja melawan pro-oksidan dengan menangkap Reactive Oxygen Species (ROS) seperti oksigen singlet, radikal superoksida, radikal hidroksil, nitrogen oksida, yang merupakan senyawa oksigen yang tidak stabil dengan elektron yang tidak memiliki pasangan dan mudah bereaksi pada jaringan, sehingga mengurangi kerusakan protein, membran lipid dan asam nukleat.11 Selain berperan sebagai antioksidan, katekin juga berperan sebagai antihiperglikemik, khususnya EGCG yang memiliki efek yang serupa dengan kerja insulin. Peranannya adalah dengan menghambat produksi glukosa hepar, mengontrol glukoneogenesis dan mengatur proses ekspresi gen dalam tranduksi sinyal insulin dan uptake glukosa. ${ }^{14}$

Berdasarkan uraian masalah tentang tingginya angka DM dan akibat yang terjadi karena keadaan hiperglikemia dan stres oksidatif yang berlebihan, serta manfaat yang ada dari tumbuhan teh (Camellia sinensis) yang kaya akan katekin yang berperan sebagai antioksidan dan antihiperglikemik, penulis tertarik mengetahui pengaruh pemberian infusa teh hijau (Camellia sinensis) terhadap penurunan kadar gula darah dan MDA serum. Peneliti tertarik melakukan percobaan terhadap salah satu hewan coba yaitu mencit (Mus musculus) yang nantinya akan diinduksi hingga menjadi keadaan diabetes dengan aloksan yang banyak digunakan untuk menginduksi keadaan diabetes pada hewan coba yang bekerja spesifik pada sel $\beta$ pankreas sehingga memunculkan keadaan hiperglikemia dan stres oksidatif, dan selanjutnya akan dilakukan perlakuan pemberian infusa teh hijau (Camellia sinensis) dan dilihat penurunan kadar gula darah dan MDA serum

\section{Metode}

Penelitian ini merupakan penelitian eksperimental dengan rancangan Randomized Posttest Control Group Design. Mencit (Mus musculus) yang dibagi menjadi 5 kelompok yaitu kelompok kontrol negatif $(\mathrm{K}-)=$ kelompok yang tidak diinduksi aloksan, kelompok kontrol positif $(\mathrm{K}+)=$ kelompok yang hanya diinduksi aloksan saja, kelompok perlakuan 1 (P1) = kelompok yang diinduksi aloksan dan diberikan infusa teh hijau $1 \%$, kelompok perlakuan $2(\mathrm{P} 2)=$ kelompok yang diinduksi aloksan dan diberikan infusa teh hijau 2\%, dan kelompok perlakuan $3(\mathrm{P} 3)=$ kelompok yang diinduksi aloksan dan diberikan infusa teh hijau $4 \%$.

Pembuatan infusa teh hijau dengan cara infus selama 25 menit dengan pelarut air pada suhu $90^{\circ} \mathrm{C}$. Infusa teh hijau diberikan menggunakan sonde setiap hari selama 15 hari. Pengambilan sampel dilakukan pada hari ke-16. Sampel untuk pengukuran kadar gula darah yaitu darah yang diambil dari vena ekor mencit. Sampel yang digunakan untuk pengukuran kadar MDA diambil melalui vena jugularis setelah diterminasi dengan cara dianastesi dan dislokasi leher. Kadar gula darah diperiksa dengan glukometer dengan metode enzimatik dan kadar MDA diperiksa dengan spektofotometer dengan metode Thiobarbituric Acid Reactive Substance (TBARS). Penelitian ini telah lolos uji etik dengan nomor surat: 508/KEP/FK/2019.

Pengolahan data dengan menggunakan analisis univariat dan bivariat, dengan sebelumnya uji normalitas Shapiro-Wilk. Analisis bivariat menggunakan uji parametrik One Way ANOVA apabila data terdistribusi normal dan homogen, dilanjutkan Post Hoc Test dengan LSD (Least Significant Difference). 
Hasil

Penelitian mengenai pengaruh pemberian infusa teh hijau terhadap glukosa darah dan MDA serum mencit yang diinduksi aloksan telah dilakukan di Laboratorium Biokimia Fakultas Kedokteran Universitas Andalas dan Laboratorium Fakultas Farmasi Universitas Andalas. Penelitian dilakukan selama 40 hari. Penelitian ini dilakukan pada 35 ekor mencit yang berusia 8-12 minggu dengan berat badan sekitar 20-40 gram yang dibagi menjadi 5 kelompok, yaitu kontrol negatif, kontrol positif, perlakuan 1, perlakuan 2 dan perlakuan 3. Teh hijau yang digunakan dibei di Kebun Teh Solok Selatan. Selama penelitian ini didapatkan dua ekor mencit mati setelah induksi aloksan, yaitu pada kelompok kontrol positif dan kelompok perlakuan 3 .

Pengukuran kadar gula darah mencit dilakukan setelah pemberian infusa teh hijau selama 15 hari. Hasil pengukuran kadar gula darah mencit setelah perlakuan dapat dilihat pada Tabel 1.

Tabel 1. Hasil Pengukuran Kadar Gula Darah Setelah Perlakuan

\begin{tabular}{cc}
\hline Kelompok & Mean \pm SD \\
\hline Kontrol Negatif & $73,14 \pm 15,29$ \\
Kontrol Positif & $210,00 \pm 5,93$ \\
Perlakuan 1 & $164,57 \pm 16,14$ \\
Perlakuan 2 & $152,57 \pm 25,70$ \\
Perlakuan 3 & $135 \pm 9,11$ \\
\hline
\end{tabular}

Berdasarkan Tabel 1, dapat dilihat bahwa ratarata kadar gula darah mencit pada kelompok kontrol negatif adalah 73,14 $\pm 15,29 \mathrm{mg} / \mathrm{dl}$, pada kelompok kontrol positif adalah 210,00 $\pm 5,93$ $\mathrm{mg} /$ dl, pada kelompok perlakuan 1 adalah 164,57 $\pm 16,14 \mathrm{mg} / \mathrm{dl}$, pada kelompok perlakuan 2 adalah $152,57 \pm 25,70 \mathrm{mg} / \mathrm{dl}$, dan pada kelompok perlakuan 3 adalah $135 \pm 9,11 \mathrm{mg} / \mathrm{dl}$.

Pengambilan sampel darah mencit untuk pengukuran MDA dilakukan di hari terakhir penelitian. Hasil pengukuran kadar MDA serum mencit setelah perlakuan dapat dilihat Tabel 2 .

Tabel 2. Hasil Pengukuran Kadar MDA Serum Setelah Perlakuan

\begin{tabular}{cc}
\hline Kelompok & Mean \pm SD \\
\hline Kontrol Negatif & $2,54 \pm 0,24$ \\
Kontrol Positif & $4,04 \pm 0,45$ \\
Perlakuan 1 & $3,05 \pm 0,28$ \\
Perlakuan 2 & $2,87 \pm 0,26$ \\
Perlakuan 3 & $2,47 \pm 0,26$ \\
\hline
\end{tabular}

Tabel 2 menunjukkan rata-rata kadar MDA serum mencit pada kelompok kontrol negatif adalah 2,54 $\pm 0,24 \mathrm{nmol} / \mathrm{mg}$, pada kelompok kontrol positif adalah $4,04 \pm 0,45 \mathrm{nmol} / \mathrm{mg}$, pada kelompok perlakuan 1 adalah $3,05 \pm 0,28$ $\mathrm{nmol} / \mathrm{mg}$, pada kelompok perlakuan 2 adalah 2,87 $\pm 0,26 \mathrm{nmol} / \mathrm{mg}$, dan pada kelompok perlakuan 3 adalah $2,47 \pm 0,26 \mathrm{nmol} / \mathrm{mg}$.

Hasil uji one way ANOVA terhadap kadar gula darah setelah perlakuan selama 15 hari menunjukan nilai $\mathrm{p}<0,05$, ini menunjukkan terdapat perbedaan yang bermakna $(p=0.000)$ kadar gula darah antar kelompok perlakuan setelah perlakuan selama 15 hari.

Hasil uji Least Significant Difference (LSD) menunjukkan adanya perbedaan yang signifikan antara kelompok kontrol positif dengan kelompok perlakuan 1 , perlakuan 2 , dan perlakuan 3 dengan $p=0,000$ dan terdapat perbedaan yang signifikan antara kelompok perlakuan 1 dengan kelompok perlakuan 3 dengan $p=0,004$. Sedangkan tidak terdapat perbedaan yang signifikan antara kelompok perlakuan 1 dengan kelompok perlakuan 2 dengan $\mathrm{p}=0,182$ dan antara kelompok perlakuan 2 dengan kelompok perlakuan 3 dengan $\mathrm{p}=0,077$.

Hasil uji one way ANOVA terhadap kadar MDA serum setelah perlakuan selama 15 hari menunjukan nilai $\mathrm{p}<0,05$, ini menunjukkan terdapat perbedaan yang bermakna $(p=0.000)$ kadar glukosa darah antar kelompok perlakuan setelah perlakuan selama 15 hari.

Hasil uji LSD terhadap kadar MDA serum menunjukkan adanya perbedaan yang signifikan antara kelompok kontrol positif dengan kelompok perlakuan 1, perlakuan 2, dan perlakuan 3 dengan $\mathrm{p}=0,000$ dan terdapat perbedaan yang signifikan antara kelompok perlakuan 3 dengan kelompok perlakuan 1 dan perlakuan 2 dengan $\mathrm{p}=0,002$ dan $p=0,026$. Sedangkan tidak terdapat perbedaan yang signifikan antara kelompok perlakuan 1 dengan kelompok perlakuan 2 dengan $p=0,273$.

\section{Pembahasan}

\section{Pengaruh Induksi Aloksan Terhadap Kadar Gula Darah}

Pada kelompok kontrol positif, perlakuan 1, perlakuan 2, dan perlakuan 3 dilakukan penginduksian aloksan dengan dosis 196 $\mathrm{mg} / \mathrm{kgBB}$ yang diberikan secara intraperitoneal untuk menimbulkan keadaan hiperglikemia pada 
mencit. Kadar gula darah diukur dengan menggunakan glukometer setelah 5 hari induksi aloksan. Pada kelompok yang diinduksi aloksan didapatkan gula darah puasa setelah induksi aloksan $\geq 135 \mathrm{mg} /$ dl yang menandakan bahwa mencit sudah berada pada keadaan hiperglikemia.

Aloksan menyebabkan degranulasi dan kerusakan struktural pada sel beta pankreas yang menyebabkan terjadinya keadaan hiperglikemia pada mencit. Aloksan bekerja dengan menghambat kerja enzim glukokinase sehingga menghambat proses oksidasi glukosa. Selain itu aloksan juga bereaksi dengan glutathione (GSH) yang berperan sebagai agen pereduksi intraselluler sehingga aloksan masuk ke dalam reaksi redoks dan secara terus-menerus membentuk ROS yang pada akhirnya akan mengakibatkan rupturnya granul sekretoris dan berlanjut pada kehilangan struktur sel beta pankreas itu sendiri. ${ }^{15}$

\section{Pengaruh Pemberian Infusa Teh Hijau Terhadap Kadar Gula Darah}

Hasil pemberian infusa teh hijau terhadap kadar gula darah pada Tabel 1 didapatkan bahwa infusa teh hijau berpengaruh dalam penurunan kadar gula darah mencit yang diinduksi aloksan. Pemberian infusa teh hijau $1 \%, 2 \%$, dan $4 \%$ secara signifikan dapat menurunkan kadar gula darah dibandingkan dengan kelompok kontrol positif. Hasil uji LSD menunjukkan bahwa kelompok perlakuan dengan infusa teh hijau $4 \%$ memiliki efektifitas yang lebih dalam menurunkan kadar gula darah dibanding kelompok perlakuan dengan infusa $1 \%$ dan $2 \%$.

Mekanisme kerja infusa teh hijau untuk menurunkan kadar gula darah sesuai dengan kandungan yang terdapat pada infusa teh hijau tersebut. Teh hijau memiliki kandungan polifenol, khususnya katekin yang berfungsi sebagai antihiperglikemik. Katekin bekerja pada proses metabolisme glukosa pada mencit pada beberapa organ. Katekin masuk ke saluran cerna dan bekerja dalam menghambat penyerapan glukosa. Mekanismenya adalah dengan menghambat transporter glukosa seperti sodium-glucose linked transporter 1 (SGLT 1) dan glucose transporter 2 (GLUT 2). Katekin pada teh hijau juga menghambat enzim pada saluran cerna seperti alfa-amilase, sukrose, dan alfa-glukosidase yang bekerja dalam penyerapan karbohidrat, sehingga berkurangnya penyerapan glukosa. Katekin juga bekerja dengan menginhibisi glukoneogenesis yang dilakukan oleh hepar dengan mengatur ekspresi gen enzim glukoneogenik, serupa seperti dengan yang juga dilakukan oleh insulin, sehingga terjadi penurunan kadar gula darah. ${ }^{16}$

Penelitian yang dilakukan oleh Haidari et al (2013) tentang suplementasi teh hijau dengan dosis $100 \mathrm{mg} / \mathrm{kgBB}$ dan $200 \mathrm{mg} / \mathrm{kgBB}$ terhadap kadar gula darah tikus diabetes. Hasil penelitian dari Haidari et al menunjukkan bahwa suplementasi teh hijau dengan dosis 200 $\mathrm{mg} / \mathrm{kgBB}$ secara signifikan dapat menurunkan kadar gula darah dibandingkan dengan dosis 100 $\mathrm{mg} / \mathrm{kgBB}$ pada tikus diabetes. ${ }^{17}$ Perbedaan hasil antara penelitian yang dilakukan dengan penelitian Haidari et al disebabkan karena perbedaan dosis, dimana dosis yang digunakan Haidari et al lebih kecil jika dikonversikan ke dosis mencit yaitu $140 \mathrm{mg} / \mathrm{kgBB}$ dan 240 $\mathrm{mg} / \mathrm{kgBB}$ dibandingkan dosis pada penelitian yang dilakukan yaitu $260 \mathrm{mg} / \mathrm{kgBB}, \quad 520$ $\mathrm{mg} / \mathrm{kgBB}$, dan $1040 \mathrm{mg} / \mathrm{kgBB}$ setelah dikonversikan dari konsentrasi infusa $1 \%, 2 \%$, dan $4 \%$. Sehingga terdapat konsentrasi yang berbeda dari katekin yang didapat, yang mengakibatkan perbedaan pengaruh pemberian teh hijau. Perbedaan lainnya adalah karena perbedaan pelarut yang digunakan, yaitu penelitian yang dilakukan menggunakan air sebagai pelarut sedangkan penelitian Haidari et al menggunakan etanol 96\%, sehingga persentase hasil ekstraksi yang dihasilkan berbeda. Hal tersebut sesuai dengan penelitian Uzunalic et al (2006) yang membandingkan efisiensi ekstraksi bahan aktif pada teh hijau. Berdasarkan penelitian tersebut didapatkan hasil bahwa pelarut air mampu menghasilkan ekstrak dengan $43 \%$ bahan aktif, lebih efisien dibandingkan pelarut etanol yang mampu menghasilkan ekstrak dengan 30\% bahan aktif. ${ }^{18}$

\section{Pengaruh Induksi Aloksan Terhadap Kadar MDA Serum}

Kadar MDA serum tertinggi terdapat pada kelompok kontol positif. Setelah diinduksi aloksan, maka akan terjadi keadaan hiperglikemia. Keadaan hiperglikemia ini nantinya akan meningkatkan produksi radikal superoksida yang disebabkan karena kurangnya SOD. Kurangnya aktivitas antioksidan seperti SOD dan GSH, yang 
disebabkan karena metabolisme glukosa yang berlebihan, semakin menambah konsentrasi peroksida yang dihasilkan, yang akhirnya semakin terjadi ketidakseimbanagan antara radikal bebas dan antioksidan. Konsentrasi radikal bebas yang tinggi ini nantinya akan berpengaruh pada PUFA yang jumlahnya banyak pada mitokondria. Karena PUFA memiliki tiga atau lebih ikatan asam lemak, membuatnya semakin sensitif untuk diserang oleh radikal bebas. ${ }^{19}$ Dalam proses peroksidasi lipid, radikal hidroksil akan membentuk radikal lipid pada tahap inisiasi. Selanjutnya radikal lipid akan menyebar dan bereaksi dengan oksigen, sehingga membentuk radikal peroksil lipid. Pada tahap akhir akan terbentuk hidroperoksida dan terurai menjadi produk sekunder yang salah satunya adalah MDA. ${ }^{20}$

\section{Pengaruh Pemberian Infusa Teh Hijau Terhadap Kadar MDA Serum}

Hasil pemberian infusa teh hijau terhadap kadar MDA serum pada Tabel 2 didapatkan bahwa infusa teh hijau berpengaruh dalam penurunan kadar gula darah mencit yang diinduksi aloksan. Pemberian infusa teh hijau $1 \%, 2 \%$, dan $4 \%$ secara signifikan dapat menurunkan kadar MDA serum dibandingkan dengan kelompok kontrol positif. Hasil uji LSD menunjukkan bahwa kelompok perlakuan dengan infusa teh hijau 4\% memiliki efektifitas yang lebih dalam menurunkan kadar MDA serum dan mendekati kadar MDA kelompok kontrol negatif dibanding kelompok perlakuan dengan infusa $1 \%$ dan $2 \%$.

Penurunan MDA serum ini disebabkan karena efek antioksidan pada teh hijau yang mengandung banyak polifenol, khususnya EGCG. EGCG bekerja sebagai antioksidan dan mampu secara langsung menangkap radikal bebas yang ada di dalam tubuh. Selain itu EGCG juga bekerja dalam menghambat terbentuknya radikal bebas dengan mengkalasi besi sehingga tidak terbentuk radikal hidroksil. Selain itu EGCG juga meningkatkan kadar antioksidan plasma dan meningkatkan aktivitas enzim antioksidase seperti katalase, SOD, dan GSH, sehingga efek radikal bebas yang timbul bisa diredam. ${ }^{14}$ Penelitian yang dilakukan Syahmar (2016) menunjukkan bahwa pemberian teh hijau mampu meningkatkan aktivitas katalase secara bermakna pada tikus diabetes. ${ }^{21}$ Penelitian yang dilakukan Mukty (2018) menunjukkan bahwa pemberian seduhan teh hijau mampu meningkatkan aktivitas SOD dan menurunkan kadar MDA serum. ${ }^{22}$ Hasil penelitian yang dilakukan Syahmar dan Mukty disebabkan kerja antioksidan yang menjadi donor elektron ke radikal bebas sehingga terhambatnya aktivitas radikal dan terjadinya peningkatan aktivitas katalase dan regulasi SOD. Penurunan aktivitas radikal bebas dan peningkatan aktivitas enzim antioksidase menyebabkan berkurangnya kejadian peroksidasi lipid, sehingga kadar MDA serum menurun.

\section{Simpulan}

Pada penelitian ini, didapatkan perbedaan yang signifikan pada kadar gula darah dan MDA serum antara kelompok mencit yang tidak diinduksi aloksan, mencit yang diinduksi aloksan, mencit yang diinduksi aloksan dengan pemberian infusa teh hijau 1\%, 2\% dan 4\%. Dari hal ini dapat disimpulkan bahwa terdapat pengaruh pemberian infusa teh hijau terhadap kadar gula darah dan MDA serum tikus yang diinduksi aloksan.

\section{Ucapan Terima Kasih}

Penulis mengucapkan terimakasih kepada semua pihak yang telah memberikan bimbingan, arahan, bantuan, dan motivasi kepada penulis sehingga penulis dapat menyelesaikan penelitian ini.

\section{Daftar Pustaka}

1. World Health Organization 2017. Diabetes. Media Centre. Diunduh dari http://www.who.int/ mediacentre/factsheets/fs312/en/. Diakses November 2018.

2. Manaf A. Insulin: mekanisme sekresi dan aspek metabolisme. Dalam: Setiati S, Alwi I, Sudoyo A, Simadibrata M, Setiyohadi B \& Fahrial A, eds. Buku Ajar Ilmu Penyakit Dalam. Jakarta:Interna Publishing; 2014, 2350-2354.

3. Bajaj S, Khan A. Antioxidants and diabetes. Indian J Endocr Metab. 2012; 16:S267-71.

4. Birben E, Sahiner UM, Sackesen C, Erzurum S \& Kalayed O. Oxidative stress and antioxidant defense. WAO Journal. 2012. 5: 9-19.

5. Yoshikawa $T$ \& Naito $Y$. What is oxidative stress. JMAJ. 2002. 45(7): 271-276.

6. Zheng Y, Ley SH \& Hu FB. Global aetiology and epidemiology of type 2 diabetes mellitus and its complications. Nature Reviews Endocrinology. 2017. 14(2): 88-98.

7. Kementrian Kesehatan RI. Riset kesehatan dasar 2013. Badan Penelitian dan Pengembangan Kesehatan. 2013.

8. Cefalu WT, Stephens JM \& Ribnicky DM. Diabetes and herbal (botanical) medicine. In: Benzie IFF, WachtelGalor S, editors. Herbal medicine: bimolecular and clinical aspects. 2nd ed. USA: CRC Press. 2011. 
9. Bhatt PR, Pandya KB \& Sheth NE. Camellia sinensis (L): the medicinal beverage: a review. 2010. 3(2): 79.

10. Namita P, Mukesh R \& Vijay KJ. Camellia sinensis (green tea): a review. Global Journal of Pharmacology. 2012. 6(2): 52-59.

11. Mahmood T, Akhtar N \& Khan BA. The morphology, characteristics, and medical properties of camellia sinensis tea. Journal of Medical Plants Research. 2010. 4(19): 2028-2033.

12. Pandey KB \& Rizvi SI. Plant polyphenols as dietary antioxidants in human health and disease. Oxidative Medicine and Cellular Longevity. 2009. 2(5): 270278.

13. Towaha J \& Balittri. Kandungan senyawa kimia pada daun teh. Warta Penelitian dan Pengembangan Tanaman Industri, 2013. 19(3): 12-16.

14. Fu QY, Li QS, Lin XM, Qiao RY, Yang R, Li XM, et all. Antidiabetic effect of tea. Molecules. 2017. 22(5): 849.

15. Ighodaro OM, Adeosun AM, Akinloye OA. Alloxaninduced diabetes, a common model for evaluating the glycemic-control potential of therapeutic compounds and plants extracts in experimental studies. Medicina. 2018

16. Sharma V, Gupta AK, Walia A. Effect of green tea on diabetes mellitus. Acta Scientific Nutritional Health. 2019. 3(7): 27-31

17. Haidari F, Omidian K, Rafiei H Zarei M, shahi MM. Green tea supplementation to diabetic rat improves serum and hepatic oxidative stress marker. Iranian Journal of Pharmaceutical Research. 2013. 12(1): 109-114

18. Uzunalic AP, Skerget M, Knez Z, Weinreinch B, Otto F, dan Gruner S. Extraction of active ingredients from green tea (Camellia sinenesis) : extraction efficiency of major catechins and caffeine. Food Chemistry. 2006. 597-605

19. Suryawanshi NP, Bhutey AK, Nagdeote N, Jadhav AA, dan Manookar GS. Study of lipid peroxide and lipid profile in diabetes mellitus. Indian Journal of Clinical Biochemistry. 2006. 21(1): 126-130.

20. Ayala A, Munoz MF, dan Arguelles S. Lipid peroxidation: production, metabolism, and signaling mechanism of malondialdehyde and 4-hydroxy-2nonenal. Hindawi. 2014.

21. Syahmar U. Pengaruh pemberian teh hijau terhadap aktivitas katalase darah pada tikus wistar diabetes melitus yang diinduksi aloksan. Universitas Andalas. 2016

22. Mukty MI. Effect of green tea (camellia sinensis) on blood glucose, mda, and sod activity. Perpustakaan Airlangga. 2018. 